\title{
Constant Temperature Artificial Incubation of Spawned Eggs in Natural Nests from the Chinese Freshwater Soft-Shelled Turtle, Tryonyx sinensis Strauch(1862)
}

\author{
Young Nam $\mathrm{Oh}^{1}$ and ${ }^{\dagger}$ Sung Han $\mathrm{Kim}^{2}$ \\ ${ }^{1}$ Jeollnam-do Ocean \& Fisheries Science Institute, Seomjin River Fish Museum \\ ${ }^{2}$ Faculty of Marine Biosciences, Kunsan National University
}

\begin{abstract}
On June 14, 2008 (the first experiment) and July 24, 2008 (the second experiment), the shores of the Boseong River and the sandy beaches, Seokgok-myun, Moksadong-myun, Gokseong-gun in Jeollanam Province were investigated and a total of 29 soft-shelled turtle (Tryonyx sinensis) eggs in the natural spawning nest eggs were collected (13 eggs were collected in the first experiment and 16 eggs in the second experiment). The temperatures in the natural spawning nests were 25.9$36.9 \pm 0.5^{\circ} \mathrm{C}$, the depth of the eggs was $5.2-7.5 \pm 0.5 \mathrm{~cm}$ as the distance of the average $6.4 \pm 0.5 \mathrm{~cm} .29$ eggs were scattered at least $0.2 \mathrm{~cm}$ interval. Artificial incubation of 29 eggs was conducted in artificial nest boxes in thermo-plastic composition of the incubator, and then incubated at $26.5-35.5 \pm 0.5^{\circ} \mathrm{C}$, and an average constant temperature was $31.2-32.1 \pm 1.0^{\circ} \mathrm{C}$. The incubation days ranged from 53 to 55 . In case of most turtles, incubation at $31{ }^{\circ} \mathrm{C}$ (higher temperatures) generally produces all or mostly females, while incubation at $25^{\circ} \mathrm{C}$ (cooler temperatures) produces all or mostly males. Exceptionally, in case of genus Trionyx, the sex ratio of female : male of $T$. sinensis of a freshwater soft-shelled turtle was approximately $1: 1$, which differs from other genera of turtles and makes $T$. sinensis Strauch only turtles presently known to lack temperature-dependent sex determination.
\end{abstract}

Key words : Trionyx sinensis, Natural nest, Constant temperature, Incubation

\section{INTRODUCTION}

The Chinese soft-shelled turtle (Chinese turtle), which is an amphibious animal that lives in freshwater and on land, belongs to the order Chelonia, and family Trionychidae. The turtle has inhabited rivers and reservoirs across Korea (Kim et al., 1978) since being released from captivity. To date, domestic research regarding the constant temperature required for artificial incubation of the Korean turtle is very limited (Gang, 1984). However, a few authors (Nakamura \& Ueno, 1984; Kaamura et al., year unknown) reported that Japanese turtles ( $T$. sinensis japonicus) hatched following incubation for 50 days at a constant temperature of $30^{\circ} \mathrm{C}$. Although the number of artificial incubation days needed for Chelydra serpentina were 63 (Yntema, 1968) and 60 (Pieau \& Dorizzi, 1981), detailed basic research regarding its natural nest has not been conducted to date. To confirm the artificial incubation days of the Chinese

\footnotetext{
Manuscript received March 12, 2017, Received in revised form March 15, 2017, Accepted March 17, 2017

${ }^{\dagger}$ Corresponding Author : Sung Han Kim, Faculty of Applied Biosciences, Kunsan National University, Gunsan, Korea. Tel: +82-10-8907-3093, E-mail: w0827@kunsan.ac.kr

This is an Open Access article distributed under the terms of the Creative Commons Attribution Non-Commercial License (http:// creativecommons.org/licenses/by-nc/3.0) which permits unrestricted non-commercial use, distribution, and reproduction in any medium, provided the original work is properly cited.
} 
soft-shelled turtle, additional studies are needed, including those investigating the ecological characteristics of the natural nest and natural incubation conditions. Such research will enable artificial incubation experiments to be conducted in a laboratory setting.

This type of research may also lead to active research regarding other reptiles such as the freshwater soft-shelled turtle, Japanese turtles, freshwater tortoises, sea turtles, and leatherback sea turtles. Turtles are also highly valued as a medicinal food or delicacy and as laboratory test animals (Ling et al., 1984). Accordingly, investigation of their artificial incubation can provide valuable information to turtle farmers.

In Korea, experimental evidence and results regarding the constant temperature artificial incubation of the Korean turtle are very limited. To date, laboratory studies have shown that incubation temperature controls sex determination in 14 genera of turtles in five families. Indeed, among the turtles that have been investigated to date, Trionyx spiniferus are the only ones presently known to lack temperature-dependent sex determination (Bull \& Vogt, 1979; Vogt \& Bull, 1982).

Two basic types of sex determination occur in reptiles: genotypic sex determination, and temperature-dependent sex determination (Bull, 1980). Genotypic sex determination is known to occur in many lizards and snakes, but only three species of turtles and for crocodiles. However, this information is likely not necessary.]. For most cryptodiran turtles and a few lizards, gender is instead determined by incubation temperature. Indeed, laboratory studies have shown that incubation temperature controls sex determination in at least seven genera of turtles. It is wellknown that incubation temperature controls sex determination in many reptiles. For example, incubation at $25^{\circ} \mathrm{C}$ produces all or mostly males, while incubation at $31{ }^{\circ} \mathrm{C}$ or higher produces all females (Bull \& Vogt, 1979; Bull et al., 1982; Yntema and Morosovsky, 1980; Vogt et al., 1982;
Vogt \& Bull, 1982). The ecology of species with temperature-dependent sex determination is interesting in control of population and family sex ratios; however, there are no detailed studies of hatching sex ratios from natural nests in these species.

Hatchling sex ratio is dependent upon different environmental parameters. To test the applicability of laboratory results to a natural population, We conducted field experiments to examine sex ratio in both experimental and undisturbed nests. The results of the experimental nests were similar to those of laboratory experiments, with hatchlings from eggs buried in the sun mostly being females, and those from eggs buried in the shade primarily being males. In addition, natural nests tended to produce only males or only females (Bull \& Vogt, 1979).

I compared observations on hatchling sex ratios from natural nests of $T$. sinensis are similar to soft-shelled turtles or similar to other kinds of turtles mentioned above. For this study, 29 eggs were collected from natural nests and then placed in an artificial incubation nest to determine if they could be hatched by constant temperature artificial incubation. The optimal temperature ranges, number of days required for hatching and hatching rates were then determined. The results presented herein will be useful to development of aquaculture of $T$. sisnensis.

\section{MATERIALS AND METHODS}

\section{Surveying for natura1 nests}

For two months from early May of 2008 (Survey 1) to late June of 2008 (Survey 2), the shores of Boseong River at Moksadong-myun and Seokgok-myun, Gokseong-gun, Jeollanamdo, Korea were studied to find turtles in natural nests and conduct basic observations (Fig. 1). As shown in Fig. 2, several turtle footprints were found on the shores every 2-3 days. As shown in Fig. 3, at natural nests were found at $6 \mathrm{pm}$ on June 14, 2008 on the shore of the river. The positions of the eggs were measured by the distance 


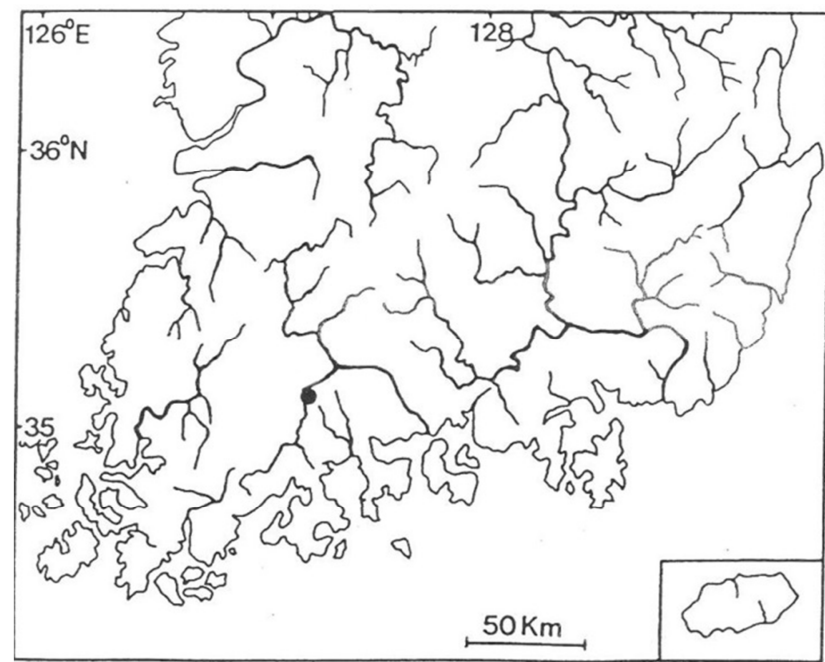

Fig. 1. A map showing the collecting area of the natral nests of a soft-shelled turtle, Trionyx sinensis.

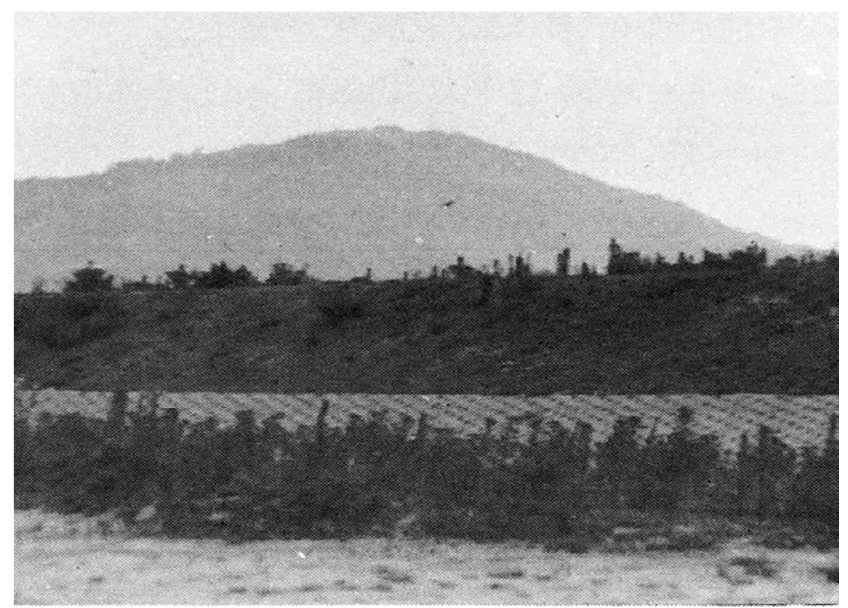

Fig. 2. A habitat of a soft-shelled turtle, Trionyx sinensis.

between the eggs and their depths were determined by the distance between the eggs and the surface. When conducting measurements, a $30-\mathrm{cm}$ ruler was used (Fig. 4). The temperatures at which eggs hatched were measured using common thermometers.

The eggs collected were transported to a constanttemperature incubation device in our laboratory in an insulated box within 90 minutes of collection. The temperature of the artificial incubator was adjusted by the average temperature of the natural state hatching conditions over one

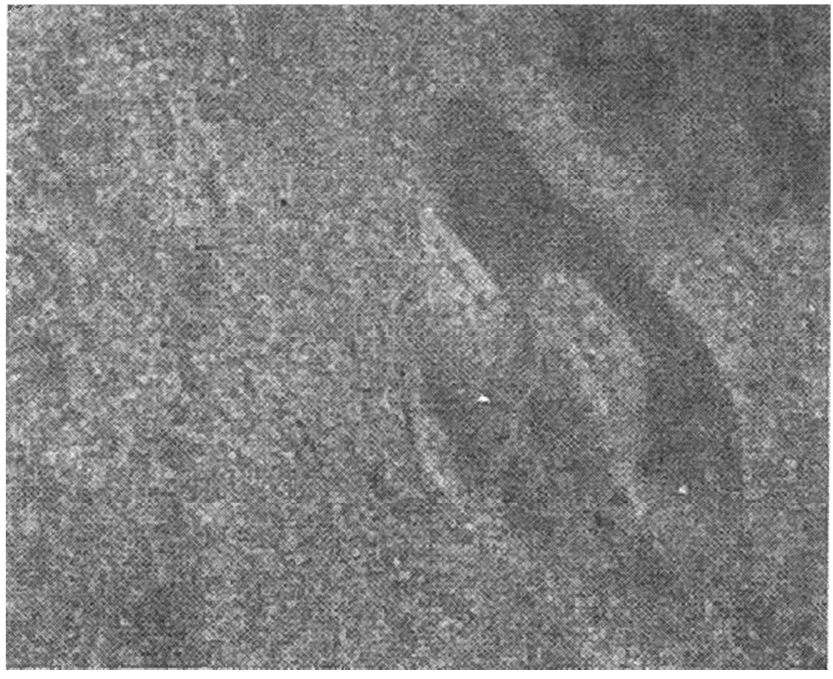

Fig. 3. Foot-track on the sand in the natural nest of a soft-shelled turtle, Trionyx sinensis.

day.

2. Egg investigation and temperatures for artificial incubation

The next day, the diameter and weight of 13 eggs (Study 1) and 16 eggs (Study 2) were determined using a Vernier caliper and Chemical balance on June 14, 2008 and July 2008. for the composition of the artificial nest incubator inside the plastic box $25 \times 30 \times 7 \mathrm{~cm}$ commercially available, such as Fig. 4 the composition was placed in a fine sands.

As shown in Fig. 5. A constant temperature of 26.5-35.5

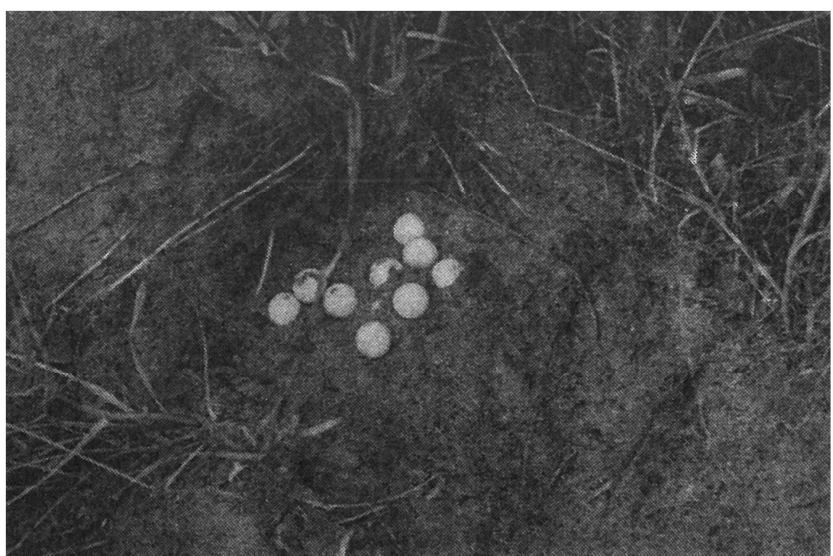

Fig. 4. Naturally spawned eggs on the natural nest of a soft-shelled turtle, Trionyx sinensis. 


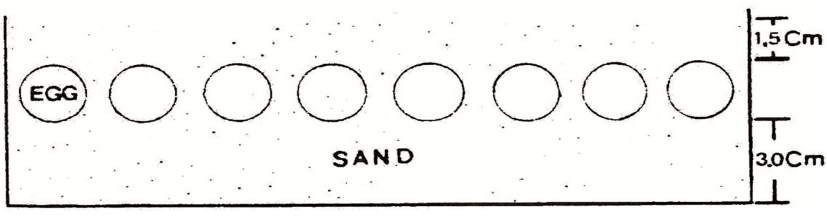

Fig. 5. A diagram of several spawned eggs of Trionyx sinensis in artificially composed nest installed in the constant temperature incubator (Model 1B 121, East Industry).

$\pm 0.5^{\circ} \mathrm{C}$ was maintained in an incubator (Model 1B 121, East Industry Co.) (Yntema \& Morosovsky, 1980; Morreale et al., 1982) in so was a sudden change.

\section{Days to egg hatching and the hatching rate}

The progress generated was studied by checking total 29 eggs in the artificial nest composed by myself every 3 to 4 according to the methods of Kawasaki et al., (year unknown) during incubation.

The hatching days were also checked daily. Hatched turtles were put in the water.

\section{RESULTS AND DISCUSSION}

1. Searching for natural incubating nests and research

Footprints and several traces of turtles were found $50 \mathrm{~m}$ from the shore of the Boseong River at Moksadong-myun and Seokgok-myun, Gokseong-gun, Jeollanamdo, which led to discovery of one natural spawning nest at 18:00 pm on June 14, 2008.

About $3.3 \mathrm{~m}^{2}$ of grass about $1 \mathrm{~m}$ in height was located to the east of one full-grown natural spawning nest in the white sandy beach was found. The average incubation temperature of 29 eggs is $30^{\circ} \mathrm{C}$.

The distances between the natural spawning eggs in the nest are shown in Figs 6 and 7. The longest interval was approximately $7.5 \mathrm{~cm}$ between egg number 3 and 10, while the shortest interval was $2 \mathrm{~mm}$ between egg number 7 and
12. Egg depths within the nests are as shown in Table 1. In the natural spawning nest, the longest distance between the eggs was $9.5 \mathrm{~cm}$ between egg number. 3 and 10, while the shortest distance was over $2 \mathrm{~mm}$ between egg no. 7 and 12 . Table 1 shows the egg depths in the natural nests. In experiment 1 (June 2008), the egg depths were as follows: four eggs at $7.5 \mathrm{~cm}$, three eggs at $6.5 \mathrm{~cm}$, two eggs at $5.9 \mathrm{~cm}$ and four eggs at $5.2 \mathrm{~cm}$, giving an average egg depth of 6.4 cm. In experiment 2 (July 2008), the egg depths were as

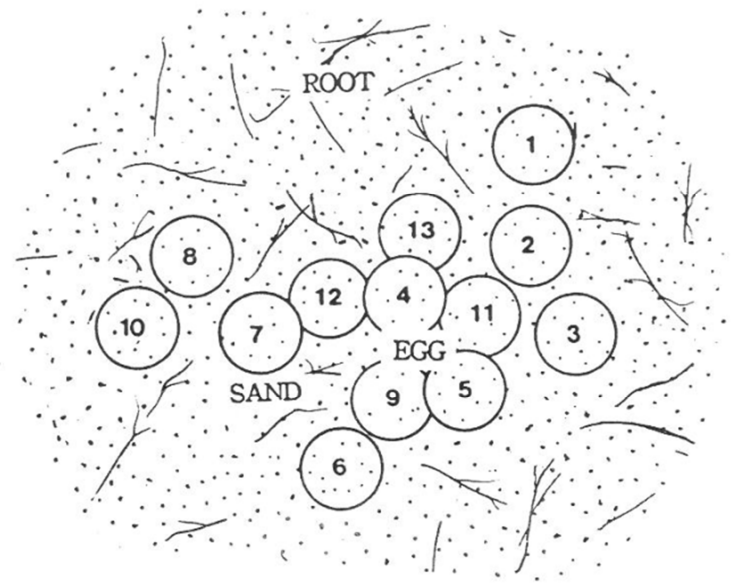

Fig. 6. Anterior view of egg distances and depths between egg numbers in the natural spawning nest of a soft-shelled turtle, Trionyx sinensis.

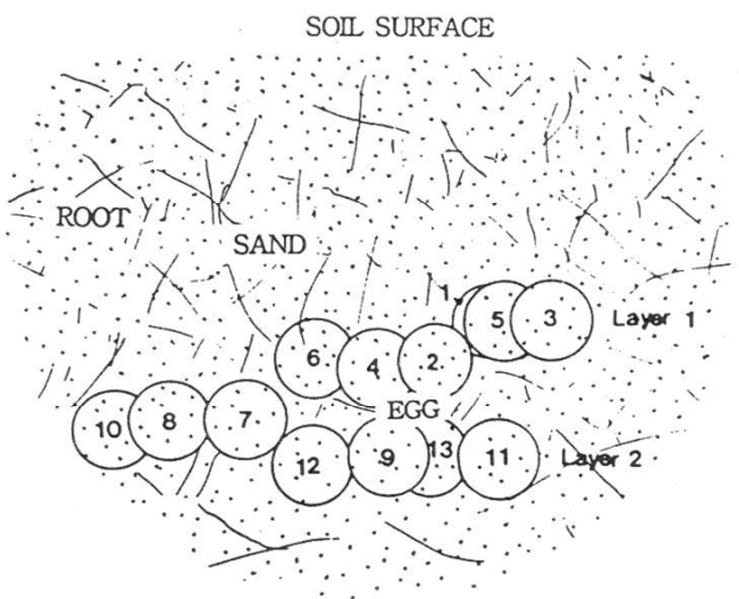

Fig. 7. Lateral view of egg depths between egg numbers, and egg arrangement formed by two layers in the natural nest of Trionyx sinensis. 
Table 1. Egg depths and incubation temperatures from two natural nests of Trionyx sinensis in the sandy beach

\begin{tabular}{|c|c|c|c|c|c|c|}
\hline \multirow{2}{*}{ Egg number } & \multicolumn{2}{|c|}{$\operatorname{Depth}( \pm 0.5 \mathrm{~cm})$} & \multicolumn{2}{|c|}{ Temperature $( \pm 0.5 \mathrm{~cm})$} & \multicolumn{2}{|c|}{ Sampling date } \\
\hline & First & Second & First & Second & First & Second \\
\hline 1 & 5.2 & 4.5 & 26.9 & 30.9 & 14 Jun. 2008 & 6 Jul. 2008 \\
\hline 2 & 5.2 & 4.5 & 26.9 & 30.9 & & \\
\hline 3 & 5.2 & 4.5 & 26.9 & 30.9 & & \\
\hline 4 & 5.2 & 4.5 & 26.8 & 30.9 & & \\
\hline 5 & 5.9 & 6.2 & 26.7 & 30.8 & & \\
\hline 6 & 5.9 & 6.2 & 26.7 & 30.8 & & \\
\hline 7 & 6.5 & 6.2 & 26.7 & 30.8 & & \\
\hline 8 & 6.5 & 6.2 & 26.3 & 30.8 & & \\
\hline 9 & 7.5 & 6.2 & 25.9 & 30.8 & & \\
\hline 10 & 6.5 & 6.8 & 26.3 & 30.8 & & \\
\hline 11 & 7.5 & 6.8 & 25.9 & 30.8 & & \\
\hline 12 & 7.5 & 6.8 & 25.9 & 30.8 & & \\
\hline 13 & 7.5 & 7.2 & 25.9 & 30.6 & & \\
\hline 14 & & 7.2 & & 30.6 & & \\
\hline 15 & & 7.2 & & 30.6 & & \\
\hline 16 & & 7.2 & & 30.6 & & \\
\hline Average & 6.4 & 6.1 & 26.4 & 30.8 & & \\
\hline Total average & & & & & & \\
\hline
\end{tabular}

follows: four eggs at $4.5 \mathrm{~cm}$, five eggs at $6.2 \mathrm{~cm}$, three eggs at $6.8 \mathrm{~cm}$, and four eggs at $7.2 \mathrm{~cm}$, giving an average depth of $6.1 \mathrm{~cm}$. Additionally, the number of eggs by constant temperature incubation were three at $26.9^{\circ} \mathrm{C}$, one at $26.8^{\circ} \mathrm{C}$, three at $26.7^{\circ} \mathrm{C}$, two at $26.3^{\circ} \mathrm{C}$, and four at $25.9^{\circ} \mathrm{C}$ for experiment 1 , giving an average of $26.4^{\circ} \mathrm{C}$. For experiment 2 , the number of eggs by constant temperature incubation were four at $30.9^{\circ} \mathrm{C}$, eight at $30.8^{\circ} \mathrm{C}$, and four at $30.6^{\circ} \mathrm{C}$, giving an average of $30.8^{\circ} \mathrm{C}$ (Table 1).

As shown in Fig. 7. The average depth of the eggs in experiment 1 was $6.4 \pm 0.5 \mathrm{~cm}$, and there were two layers. Moreover, it is estimated that there was no direct contact between the incubations. During development, eggs con- taining an embryo should be isolated from dead eggs and non-fertilized eggs owing to gas exchange by the embryo. Perhaps, it is estimated to be a spawn way to protect the eggs from birds and mammals.

\section{Egg investigation and artificial incubation tem-} perature

Table 2 shows the diameters of the eggs (based on the long diameter). In experiment 1 , five eggs had a diameter of $21.2 \mathrm{~mm}$ and four had a diameter of $21.1 \mathrm{~mm}$, respectively. Of the total 13 eggs in experiment 1, the average egg diameter was 21.2. In experiment 2, 10 eggs had diameters of $21.6 \mathrm{~mm}$, while five had diameters of $21.5 \mathrm{~mm}$, and one had a diameter of $21.3 \mathrm{~mm}$, giving an average egg 
Table 2. Diameters and weights of egg in the two natural nests from sandy beach

\begin{tabular}{|c|c|c|c|c|c|c|c|c|}
\hline \multirow{3}{*}{ Egg number } & \multicolumn{4}{|c|}{ Egg diameter $( \pm 1.0) \mathrm{mm}$} & \multirow{2}{*}{\multicolumn{2}{|c|}{$\begin{array}{c}\text { Egg weight } \\
( \pm 0.1) \mathrm{g}\end{array}$}} & \multirow{2}{*}{\multicolumn{2}{|c|}{ Sempling date }} \\
\hline & \multicolumn{2}{|c|}{ High } & \multicolumn{2}{|c|}{ Low } & & & & \\
\hline & First & Second & First & Second & First & Second & First & Second \\
\hline 1 & 21.2 & 21.6 & 20.6 & 19.4 & 5.2 & 4.7 & 14 Jun. 2008 & 6 Jul. 2008 \\
\hline 2 & 21.3 & 21.6 & 20.7 & 19.4 & 5.3 & 4.7 & & \\
\hline 3 & 21.3 & 21.5 & 20.5 & 19.3 & 5.3 & 4.5 & & \\
\hline 4 & 21.2 & 21.6 & 20.7 & 19.5 & 5.3 & 4.6 & & \\
\hline 5 & 21.3 & 21.5 & 20.5 & 19.3 & 5.3 & 4.6 & & \\
\hline 6 & 21.1 & 21.5 & 20.6 & 19.3 & 5.2 & 4.6 & & \\
\hline 7 & 21.1 & 21.6 & 20.5 & 19.5 & 5.3 & 4.7 & & \\
\hline 8 & 21.3 & 21.6 & 20.6 & 19.4 & 5.3 & 4.7 & & \\
\hline 9 & 21.2 & 21.6 & 20.6 & 19.4 & 5.2 & 4.6 & & \\
\hline 10 & 21.2 & 21.6 & 20.7 & 19.4 & 5.2 & 4.5 & & \\
\hline 11 & 21.1 & 21.6 & 20.5 & 19.4 & 5.2 & 4.7 & & \\
\hline 12 & 21.2 & 21.5 & 20.5 & 19.3 & 5.3 & 4.7 & & \\
\hline 13 & 21.1 & 21.3 & 20.6 & 19.5 & 5.2 & 4.7 & & \\
\hline 14 & & 21.5 & & 19.3 & & 4.6 & & \\
\hline 15 & & 21.6 & & 19.4 & & 4.7 & & \\
\hline 16 & & 21.6 & & 19.4 & & 4.7 & & \\
\hline Average & 21.2 & 21.6 & 20.6 & 19.4 & 5.25 & 4.64 & & \\
\hline Total average & 1st : & 20.9 & 2nd: & 20.5 & & & & \\
\hline
\end{tabular}

diameter of 21.6.

Table 2 also shows the short diameters of the eggs. In the experiment 1, three eggs had a diameter of $20.7 \mathrm{~mm}$, five had a diameter of $20.6 \mathrm{~mm}$, and five had a diameter of $20.5 \mathrm{~mm}$, giving an average egg diameter of $5.25 \mathrm{~mm}$. In experiment 2, three eggs had a diameter of $19.5 \mathrm{~mm}$, eight had a diameter of $19.4 \mathrm{~mm}$, and five had a diameter of 19.3 $\mathrm{mm}$, giving an average of $19.4 \mathrm{~mm}$.

The egg weight is also shown in Table 2. In experiment 1 , seven eggs weighed $5.3 \mathrm{~g}$ and six weighed $5.2 \mathrm{~g}$, giving an average of $5.25 \mathrm{~g}$. In experiment 2, nine eggs were $4.7 \mathrm{~g}$, five were $4.6 \mathrm{~g}$ and two were $4.5 \mathrm{~g}$, giving an average of $4.64 \mathrm{~g}$.
The hatching rates are shown in Table 3. The constant temperatures in experiment 1 and 2 were $21.2 \pm 1.0^{\circ} \mathrm{C}$ and $32.1 \pm 1.0^{\circ} \mathrm{C}$. In experiment 1 , hatching occurred between days 53 and 55. Specifically, six eggs (46.1\%) hatched at day 53 days, while the remaining eggs had hatched by day 55 (100\% hatching rate). In experiment 2 , two (12.5\%) of the eggs hatched on day 47 , and the remaining eggs had hatched by day $50(100 \%)$. Overall, there was a $100 \%$ hatching rate for both experiments (Table 3 ).

A total of 29 eggs collected from the natural spawning nests were artificially incubated at $29-35.5 \pm 1.0^{\circ} \mathrm{C}$ of artificial nests placed at random in a constant temperature incubator a plastic box $(25 \mathrm{~cm} \times 30 \mathrm{~cm} \times 7 \mathrm{~cm})$ randomly 
Table 3. Incubation days and hatching rates of 29 eggs from two natural nests by the constant temperature incubator

\begin{tabular}{|c|c|c|c|c|c|}
\hline \multicolumn{3}{|c|}{$\begin{array}{l}\text { Temperature of egg incubation } \\
\qquad\left(31.2 \pm 1.0^{\circ} \mathrm{C}\right)\end{array}$} & \multicolumn{3}{|c|}{$\begin{array}{l}\text { Temperature of egg incubation } \\
\qquad\left(32.1 \pm 1.0^{\circ} \mathrm{C}\right)\end{array}$} \\
\hline $\begin{array}{l}\text { Incubation } \\
\text { days }\end{array}$ & $\begin{array}{c}\text { No } \\
\text { of eggs }\end{array}$ & $\begin{array}{l}\text { Hatching rate } \\
(\%)\end{array}$ & $\begin{array}{c}\text { Incubation } \\
\text { days }\end{array}$ & $\begin{array}{c}\text { No } \\
\text { of eggs }\end{array}$ & $\begin{array}{c}\text { Hatching rate } \\
(\%)\end{array}$ \\
\hline 53 & 6 & 46.1 & 47 & 2 & 12.5 \\
\hline 54 & 4 & 30.8 & 48 & 4 & 25.0 \\
\hline \multirow[t]{2}{*}{55} & 3 & 23.1 & 49 & 7 & 43.8 \\
\hline & & & 50 & 3 & 18.7 \\
\hline 54 & 13 & 100 & 49 & 16 & 100 \\
\hline
\end{tabular}

composed. Each one day was incubated at $26.5^{\circ} \mathrm{C}, 29^{\circ} \mathrm{C}$, $35.5^{\circ} \mathrm{C}$, respectively. And also, the other incubation temperatures $\left(30,31,32,33,33.5,34.5^{\circ} \mathrm{C}\right)$ were added. Overall, the average daily incubation temperature was $31.2 \pm 1.0$ ${ }^{\circ} \mathrm{C}$, which is in accordance with a study conducted by Baskerville \& Emin (1969).

3. Incubation days until hatching and the incubation rate

As shown in Table 3 and Fig. 8, the number of incubation days ranged from 53 to 55 days (average, 54 days). At 53 days there were six hatchlings ( $46.1 \%$ hatching rate); at 54 days there were four hatchlings (30.8\% hatching rate) and at 55 days there were three hatchlings (23.1\% hatching

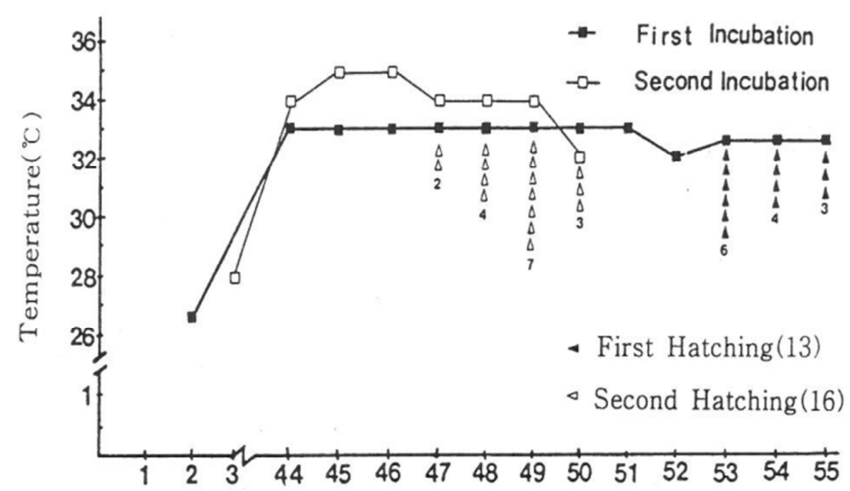

Fig. 8. Daily changes in incubation temperatures in the constant incubator, and incubation days elapsed until hatching. rate). There are 3 kinds of incubation days: the hatching rate was the highest with $46.1 \%$ (hatching rate) on 53 days (incubation days), However, 55 days (the lowest hatchability $23.1 \%$ (3 hatchlings). The total hatching rate was 100 $\%$. The external morphological characteristics (the carapace sizes and patterns) of the 13 individuals were similar.

At 18:00 June 13, 2008, we visited the shores of Boseong River at Moksadong-myun and Seokgok-myun, Gokseong-gun, Jeollanamdo, at which time footprints of $\mathrm{Tr}$ yonyx sinensis Strauch were discovered on the beach. One case was from a natural spawning nest covered with grass (over $1 \mathrm{~m}$ in height) were located in the white sandy beach and sand mixed with soil, as the riverside hills toward the east direction (Charistens \& Bider, 1986). As it were, rapid changes in temperature is not occur, it's a place covered with grass bed near white sand bed.

1) Ranges of natural incubation temperatures of eggs

As shown in Table 1, the natural incubation temperature of the eggs ranged from 25.9 to $26.9 \pm 0.5^{\circ} \mathrm{C}$. The number of eggs and incubation temperatures were as follows: 4 eggs at $25.9^{\circ} \mathrm{C} ; 2$ eggs at $26.3^{\circ} \mathrm{C} ; 3$ eggs at $26.7^{\circ} \mathrm{C} ; 1$ egg at $26.8^{\circ} \mathrm{C} ; 3$ eggs at $26.9^{\circ} \mathrm{C}$. The average incubation temperature was $26.4 \pm 0.5^{\circ} \mathrm{C}$ in the natural nests.

The long egg diameters in the natural nests were as fol- 
lows: $21.3-21.1 \pm 1.0 \mathrm{~mm}$ (average, $21.2 \pm 1.0 \mathrm{~mm}$ ), while the short egg diameters were 20.5-20.6 $\pm 1.0 \mathrm{~mm}$ (average, $20.6 \pm 1.0 \mathrm{~mm})$. The overall, egg diameter was close to the sphere of the same size as $20.9 \pm 1.0 \mathrm{~mm}$.

The minimum weight of the natural eggs was $5.2 \pm 0.1 \mathrm{~g}$, while the maximum weight was $5.3 \pm 0.1 \mathrm{~g}$, and the average was $5.25 \pm 0.1 \mathrm{~g}$. Overall, the sizes, shapes and weights of the 13 eggs were similar.

Artificial egg incubation is given the number of eggs collected during the natural spawning nests placed in any of the compositions of artificial nests in plastic boxes $(25 \times 30 \times 7 \mathrm{~cm})$ sizes of the market, was incubation incubator at a constant temperature in the range 29-35.5 $\pm 1.0^{\circ} \mathrm{C}$, $35.5 \pm 1.0^{\circ} \mathrm{C}$, one days of incubation at that temperature is considered for even a short time can be suspended in accordance with the normal incubation occurs did not have a serious adverse effect. The average incubation temperature a whole day will be able to fall within the high temperature as generally as $31.2 \pm 1.0^{\circ} \mathrm{C}$.

As shown in Fig. 8, incubation days are eggs collected during the natural spawning 29 eggs in natural nests, they were hatched the incubation by natural incubation temperature of an average $30^{\circ} \mathrm{C}$, incubation days reported by Kawasaki and Iwao (year unknown) were similar. It was 53-55 days, including the days of natural incubation 2 days to 53 days incubation 6 individuals, 54 days individuals, the individuals as a three-day average of 54 days has been estimated as incubation days (54 days) reported by Yntema (1968), and approximately 49-50 days has been estimated by Pieau \& Dorizzi(1981).

The hatching rate of this species was $100 \%$. The appearance and physical characteristics of the turtles were similar. The similarity of these animals, is believed to be due to genetic factors, which is considered to have a significant meaning.

As shown in Table 3, the above results were obtained from research based on natural spawned eggs collected in the natural nests, in the composition of the artificial nest, nesting been arbitrary composition in a plastic box no doubt useful for artificial incubation, incubation temperature range of $26.5-35.5 \pm 1.0^{\circ} \mathrm{C}$ was found two incubation possibility of the mean incubation temperature of $31.2 \pm$ $1.0^{\circ} \mathrm{C}$ under, embryo development of these days incubation days in the average incubation temperature of turtles were average 54 days for 13 eggs (hatching rate 100\%). And also incubation days were average 49 days for 16 eggs at constant temperature of $32.1 \pm 1.0^{\circ} \mathrm{C}$ (hatching rate $100 \%$ ). These findings indicate that the incubation system used here can be useful as an artificial nest, and a large number of reptiles can be produced by constant temperature artificial incubation.

\section{2) Sex ratios}

In these studies (the 1 st experiment for 13 eggs, and $2^{\text {nd }}$ experiment for 16 eggs), we analyzed thir sex ratios of $T$. sinensis.

1) In the first experiment, of total 13 individuals, 7 males and 6 females were hached (Table 4). There was no significant different in the prevalence of each sex (not different from 1:1 sex ratio, $\chi^{2}=0.08, P>0.05$ ).

2) In the $2^{\text {nd }}$ experiment, of total 16 individuals, 7 males and 9 females were hatched (Table 4). There was no significant different in the prevalence of each sex (not different from 1:1 sex ratio, $\left.\chi^{2}=0.25, P>0.05\right)$. Comparisons between the $1^{\text {st }}$ and $2^{\text {nd }}$ experiments showed no statistical differences (the sex ratios of males and females were 1:1).

In general, the sex of many reptiles is determined by incubation temperature. According to the laboratory studies of 14 genera of turtles in five families show that a developmental temperature of $25^{\circ} \mathrm{C}$ produces all males in most species, and that $31^{\circ} \mathrm{C}$ or higher produces all females. However, recently, in case of genus Trionyx of freshwater soft-shelled turtles, exceptionally, at higer temperatures 
Table 4. Sex ratio of males and females by constant temperature incubations

\begin{tabular}{|c|c|c|c|c|c|c|c|}
\hline \multicolumn{4}{|c|}{$\begin{array}{l}\text { Temperature of egg incubation } \\
\text { (the 1st Exp. 2008) }\end{array}$} & \multicolumn{4}{|c|}{$\begin{array}{l}\text { Temperature of egg incubation } \\
\text { (the 2nd Exp. 2008) }\end{array}$} \\
\hline \multirow{2}{*}{$\begin{array}{l}\text { Incubation } \\
\text { days }\end{array}$} & \multirow{2}{*}{$\begin{array}{l}\text { No. of } \\
\text { eggs }\end{array}$} & \multicolumn{2}{|c|}{ Sex ratio $^{1)}$} & \multirow{2}{*}{$\begin{array}{c}\text { Incubation } \\
\text { days }\end{array}$} & \multirow{2}{*}{$\begin{array}{l}\text { No. of } \\
\text { eggs }\end{array}$} & \multicolumn{2}{|c|}{ Sex ratio $^{2)}$} \\
\hline & & Male & Female & & & Male & Female \\
\hline 53 & 6 & $50.0(3)$ & $50.0(3)$ & 47 & 2 & $50.0(1)$ & $50.0(1)$ \\
\hline 54 & 4 & $50.0(2)$ & $50.0(2)$ & 48 & 4 & $25.0(1)$ & $75.0(3)$ \\
\hline \multirow[t]{2}{*}{55} & 3 & $66.7(2)$ & $33.3(1)$ & 49 & 7 & $57.1(4)$ & $42.9(3)$ \\
\hline & & & & 50 & 3 & $33.3(1)$ & $66.7(2)$ \\
\hline 54 & 13 & $53.8(7)$ & $46.2(6)$ & 49 & 16 & $43.8(7)$ & $56.2(9)$ \\
\hline
\end{tabular}

(overt $30-31{ }^{\circ} \mathrm{C}$ ) or cooler temperatures (about $25^{\circ} \mathrm{C}$ ), the sex ratios of females and males of Trionyx species produces always 1:1 at some different temperatures. In this studies we could confirm the sex ratios. According to Bull and vogt (1972), they confirmed sex ratios of males and females from American turtles of T. spiniferus (genus Trionyx). Therefore, exceptinally we can find these phenomena. Perhaps, these phenomena may occur or develop by gene variation by a certain adaptation.

Field studies suggest that nest temperature is chief agent determining sex. The sex ratio of natural population may be influenced by climatic changes, but natural selection on maternal choice of nest sites and on the embronic control of sex determination may compensate for climatic change and bring the sex ratio to the equilibrium.

\section{REFERENCES}

Baskerville GL, Emin P (1969) Rapid estimation of heat accumulation from maximum and minimum temperatures. Ecology 50:514-517.

Bull JJ, Vogt RC (1979) Temperature-dependent Sex Determination in Turtles. Science Washington. D. C. (1983).
206: 1186-1188.

Bull JJ, Vogt RC, McCoy CJ (1982) Sex determining temperature in turtles: a geographic comparison. Evolution (Lawrence. Kans) 36: 326-332.

Charistens E, Bider JR (1986) Reproductive ecology of the painted turtle (Chrysemys picta marginata) in southern-eastern Quebec. Can J Zool 64: 914-920.

Gang SW (1984) Freshwater Fish Framing. Sunjinmunwhasa. pp. 356-361.

Illustrated Encylopedia of Fauna \& Flora of Korea. Vol. 17. (Amphibia - Reptilia) (1975) Ministry of Education, Samwha Publishing company.

Kawasaki YK, Iwao S (Year unknown). Studies on egg developments of the freshwater soft-shelled tutles, Trionyx sinensis japonicus. Unknown Society Name. pp. $1-3$.

Kawamura AT, Ooya ST, Ishida RZ, Kazi SM, Suzuki NO, (Year unknown). Fish farming course (Vol. 5). Midorishobo pp. 191-261.

Kim HG, Gang SW, Moon HS (1978) Ecology of Korean Vertebrates. Ilsinsa, pp. 159-186.

Ling EA, Gopalakrishnakone P, Voon FCT (1984) Epiplexus cells in the embryos of the turtle, Trionyx sinen- 
sis. Arch Histol Jap 48(4):355-361.

Morreale SJ, Ruiz GJ, Spotila JR, Standora EA (1982) Temperature dependent sex determination: current practices threaten conservation of sea turtles. Science (Washington, D. C., 1883-) 216:1245-1247.

Nakamura KN Ueno JN (1963) Encyclopedia Zoologica illustrated in colours of Japan (Amphibia $\cdot$ Reptilia). Hoikusha pp. 83-84.

Pieau CR, Dorizzi M (1981) Determination of temperature sensitive stages for sexual differentiation of the gonads in embryos of the turtle, Emys orbicularis. J Morpho 170:373-382.

Vogt RC, Bull JJ (1982) Temperature controlled sex de- termination in turtles: ecological and behavioural aspects. Herpertologica 38:156-164.

Vogt RC, Bull JJ, McCoy CJ, Housal TW (1982) Incubation temperature influences sex determination in $\mathrm{Ki}$ nosternid turtles. Copeia 480-482.

Yntema CL (1968) A series of stages in the embryonic development of Chelydra serpentina. J Morph 125: 219-252.

Yntema CL, Morosovsky N (1980) Sexual differentiation in hatchling loggerheads (Carreta caretta) incubated at different controlled temperatures. Herpetologica 36: 33-3. 